\title{
MICROBIAL POPULATIONS OF CRUDE OIL SPILL POLLUTED SOILS AT THE JORDAN-IRAQ DESERT (THE BADIA REGION)
}

\author{
Ismail Saadoun ${ }^{1 *}$; Munir J. Mohammad²; Khalid M. Hameed ${ }^{3}$; Mo'ayyad Shawaqfah ${ }^{4}$ \\ ${ }^{1}$ Department of Applied Biological Sciences; ${ }^{2}$ Department of Natural Resources and Environment; ${ }^{3}$ Department of Plant \\ Protection, Jordan University of Science and Technology, Irbid-22110, Jordan; ${ }^{4}$ Deptarment of Civil and Environmental \\ Engineering, Mu’tah University, Karak-61710, Jordan
}

Submitted: September 06, 2007; Returned to authors for corrections: December 15, 2007; Approved: July 14, 2008.

\begin{abstract}
Microbial populations' inhabitants in crude petroleum contaminated soils were analyzed in relation with the soil characteristics. A noticeable greater decline of bacterial counts and diversity but a prevalence of the genus Pseudomonas over the other identified genera in the fresh contaminated soils as compared to the old ones was observed.
\end{abstract}

Key-words: Bacteria; Crude oil; Fungi; Soil; Streptomycetes.

Bacteria and fungi are known to be the principal agents of hydrocarbon biodegradation. Such organisms are readily isolated from soil and it was reported that the introduction of oily wastes into soil caused appreciable increases in the numbers of both groups $(7,11,15)$. Although soil counts cannot be used for analysis of biodegradability of the spilled hydrocarbons, the diversity and the number of microorganisms at a given site may help to characterize that site with respect to the toxicity of these hydrocarbons to the microbiota, age of the spill and concentration of the pollutant. In addition, microbial isolates from the soils that are historically exposed to hydrocarbon pollution exhibit a higher potential of biodegradation than others with no history of such exposure. For that matter, in a crude petroleum-polluted soil, the biodiversity and microbial prevalence of certain microbe(s) may indicate how well the soil is supporting the growth of that microbe(s) (4). Fresh spills and/or high levels of pollutants often kill or inhibit large sectors of the soil microbial population, whereas soils with lower levels or old pollution show greater numbers and diversity of microorganisms $(3,6,10,19)$.

During the decade of 1991-2001, the petroleum needs of Jordan were covered by road tanker transportation from Iraq using the highway across the eastern territory of what is known as the "Jordan Badia". According to the report No. 824 and dated 4/7/2001 issued by the Civil Defense Department by the Mafraq Governate in Jordan (5) a total of 290 traffic accidents with petroleum tankers occurred on that highway. In many accidents, 50,000 liters of crude petroleum oil were spilled. Therefore, there has been a growing interest and concern about the impact of such pollution upon the soil microbial diversity and their population. In the present study, efforts were taken to investigate the microbial populations (bacteria, streptomycetes and fungi) and their diversity in both polluted and non polluted soils (control). The differences in soil characteristics at two depths $(1-10$ and $10-20 \mathrm{~cm})$ for all sampled locations were taken in consideration in sampling at different sites.

Badia region is part of the Syrian Desert and situated on the northwestern edge of the Arabian Desert. Spellings of localities names in this region were adopted from the official standard names gazetteer of Jordan (1).

During the summer of 2001, soil samples were collected from different crude oil polluted sites inflicted by transportation trailer truck accidents along the high-way running between Iraq and Jordan. After removing a approximately $3 \mathrm{~cm}$ surface layer, soil samples were pulled out from two depths of $10 \mathrm{~cm}$ and $20 \mathrm{~cm}$. Control samples were also collected from polluted soil several meters away from the polluted spots. All soil sampled were carried inside sterile labeled polyethylene plastic bags protected

*Corresponding Author. Mailing address: Department of Applied Biological Sciences, Jordan University of Science and Technology, P.O. Box 3030, Irbid- 22110, Jordan. Phone: +962-2-7201000-Ext. 23460, Fax: +962-2-7201071. E-mail address: isaadoun@just.edu.jo 
from direct sunlight and transported to the lab for further analysis.

Each soil sample was crushed, thoroughly mixed and sieved through a $2 \mathrm{~mm}$ pore size mesh (Retsch, Germany) to get rid of large debris. Samples awaiting microbial analysis were placed in polyethylene bags, tightly closed and stored inside a refrigerator at $4 \pm 1^{\circ} \mathrm{C}$.

Each soil sample was thoroughly mixed and its moisture content was measured by drying of one $\mathrm{g}$ of soil at $65^{\circ} \mathrm{C}$ inside an oven (WTB Binder, Germany) overnight. The difference between the original and dry weight represented the moisture content. Total petroleum hydrocarbon (TPH) in these polluted soil samples was determined by constitutive extraction of $10 \mathrm{~g}$ of soil with hexane, dichloromethane and chloroform (100 ml each). The three extracted portions were pooled and dried at room temperature by evaporation of solvent in a fume hood (CMS, Spain). After solvent evaporation the amount of residual TPH was determined gravimetrically according to procedures outlined by Williams et al. (20). The soil $\mathrm{pH}$ was measured in 1:1 soil:water suspension and organic matter was measured by oxidation (12).

Sub samples of $1 \mathrm{~g}$ were suspended in $100 \mathrm{ml}$ of sterile distilled water, agitated on a water-bath shaker $\left(100 \mathrm{rpm}\right.$ at $28^{\circ} \mathrm{C}$ for 30 $\mathrm{min})$. Suspension of each soil sample was allowed to settle down and then serial ten-fold dilutions were prepared. Aliquots of 0.1 $\mathrm{ml}$ were taken from each dilution and evenly spread with the aid of sterilized L-shaped glass rod over the surface of either nutrient agar, starch casein nitrate agar (SCNA) (8) or malt extract agar in Petri dishes for the estimation of bacterial, streptomycetal and fungal counts, respectively. All plates were incubated for $48 \mathrm{~h}$ at $27^{\circ} \mathrm{C}$ except SCNA plates which were incubated for 10 days. Cultures with $20-200$ colonies per plate at $27^{\circ} \mathrm{C}$ were chosen for estimation of streptomycetes count. Single colony isolation of Streptomyces was made by repeated streaking on SCNA plates for the purpose of purification of bacterial colonies that showed a Streptomyces-like appearance.

The morphological characterization of each isolate was first performed by noticing color, size, and colony characteristics (form, margin, and elevation), and Gram staining reaction. The following biochemical tests were used for identification: gelatin liquefaction, citrate utilization, oxidase, catalase, growth at $6.5 \%$ sodium chloride, fluorescent pigment production, indole formation, and glucose fermentation. The ability of the isolates to grow at $42^{\circ} \mathrm{C}$ was also detected.

All isolates recovered on SCNA plates were screened based on their colony morphology, resembling that of Streptomyces species and matching the genus description as reported by Shirling and Gottlieb (18), Nonomura (13) and Williams et al. (21).

Although microbial enumeration is not a direct measure of activity in soils, data obtained here could be used to infer toxicity of the hydrocarbons to soil microbiota.
In this study, microbial populations of crude petroleumpolluted soil counts ranged from $1.52 \times 10^{5}$ to $237.5 \times 10^{5} \mathrm{CFU} / \mathrm{g}$ soil at a depth of $1-10 \mathrm{~cm}$ with 2 different colony types of bacterial strains (Table 1). However, the count at a depth of 10$20 \mathrm{~cm}$ ranged from $1.5 \times 10^{5}$ to $83 \times 10^{5} \mathrm{CFU} / \mathrm{g}$ soil and only one colony type for each of the recovered microbial groups was observed. Results revealed that the bacterial count at a depth of 10-20 cm declined to $65-95 \%$ when compared to a depth of 1$10 \mathrm{~cm}$. Streptomycetes and fungal counts at the two depths of collection $(10 \mathrm{~cm}$ and $20 \mathrm{~cm})$ were also different. There were higher counts and more diversified colony types at a depth of $10 \mathrm{~cm}$ than at $20 \mathrm{~cm}$. There were higher microbial populations in the upper layer of polluted soil $(1-10 \mathrm{~cm})$ than in the lower layer $(10-20 \mathrm{~cm})$. This could be due to the oil pollution becoming, with time, concentrated in the lower soil strata. Furthermore, at that depth it is protected from the effects of dissipation factors such as sun light, temperature and wind, thus toxic effect would be pronounced upon soil microbial inhabitants. In contrast to that finding, control samples showed microbial count ranging between $1.24 \times 10^{7}$ and $2.98 \times 10^{7} \mathrm{CFU} / \mathrm{g}$ soil for the bacteria, between $3 \times 10^{3}$ and $8 \times 10^{4} \mathrm{PFU} / \mathrm{g}$ soil for the streptomycetes and between 78 and $355 \mathrm{PFU} / \mathrm{g}$ soil for fungi.

Data showed the average organic percentage content in the polluted soils was $4.53 \%$ as compared to $0.095 \%$ in the control unpolluted soils, reflecting an increase of about $98.5 \%$. The $\mathrm{TPH}$ also was increased by an average of $73 \mathrm{mg} / \mathrm{g}$ soil ( $(94.5 \%)$. Crude oil polluted soils severely reduced the three microbial populations and data revealed that bacterial, streptomycetal and fungal counts were reduced by fraction of about $92 \%, 50-$ $67 \%$ and $54.5-80.8 \%$, respectively compared to counts revealed in the control samples.

It seems that different environmental conditions as well as the activities of the microbial populations play a role in degradation of the hydrocarbon contaminants. This is reflected in more occurrences of these populations with less TPH and organic matter in the aged polluted sites as compared to fresh spilled sites. Atlas (2) and Leahy and Colwell (10) reported that the rate of petroleum hydrocarbon biodegradation in nature is determined by the populations of indigenous hydrocarbon degrading microorganisms, the physiological capabilities of those populations, plus other various a biotic factors that may influence the growth of the hydrocarbon-degraders. In their investigation, Leahy and Colwell (10) concluded that hydrocarbon biodegradation depends on the composition of the microbial community and its adaptive response to the presence of hydrocarbons. In addition, the distribution of type and the number of microorganisms at a site may help to characterize the site with respect to concentration and age of the contaminant. Fresh spills and/or high levels of contaminants often kills or inhibit a large sector of the soil microbiota, whereas soils with lower levels of aged contamination show a greater number and diversity of microorganisms $(3,6,10,19)$. Saadoun (17) observed 


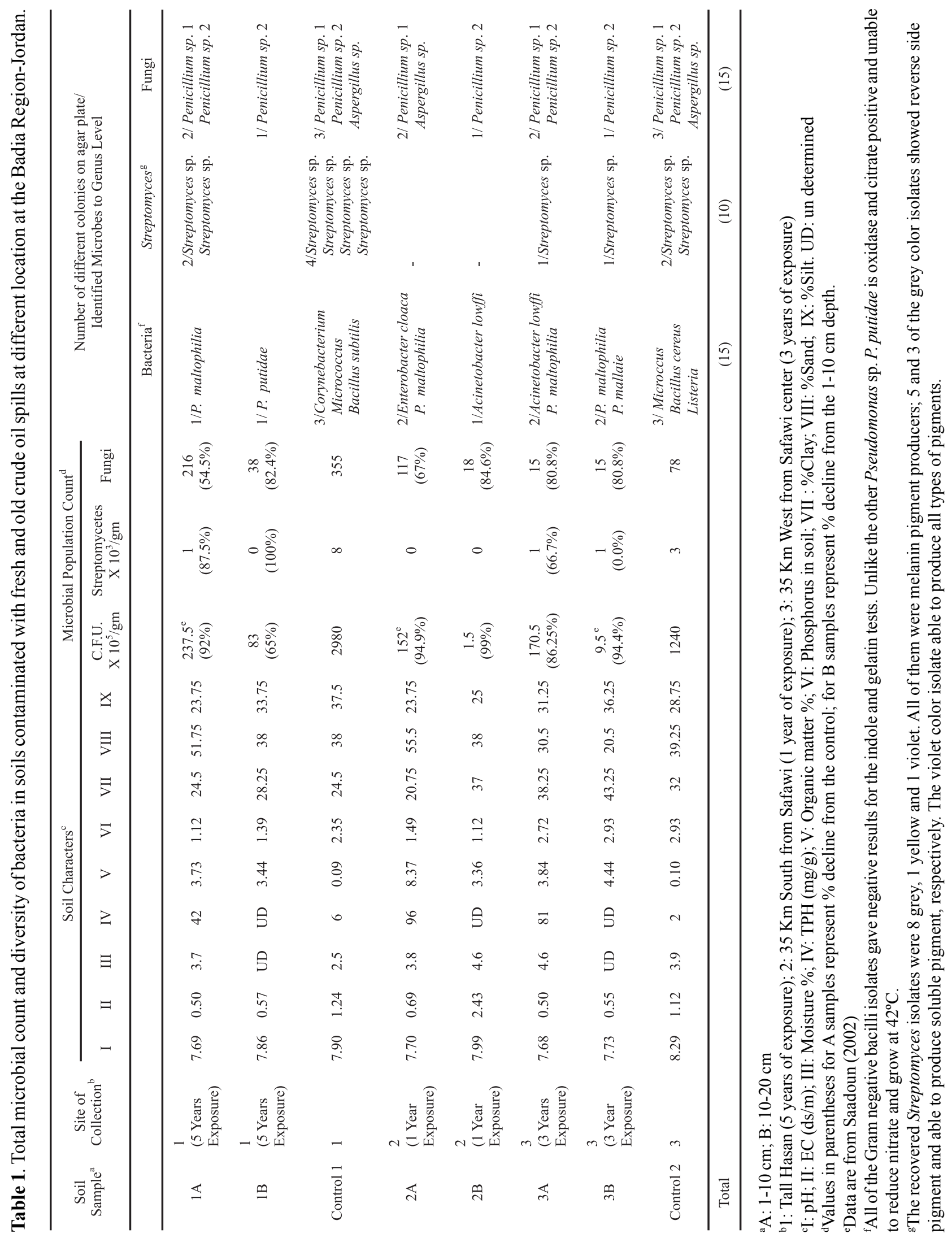


that old-contaminated soils showed greater numbers of microorganisms, whereas fresh-contaminated soils showed lower numbers. This is also clear in this study where oldcontaminated soils showed a greater number of microorganisms, whereas fresh-contaminated soils showed lower population numbers and diversity in their microbial content.

Data showed that maximum bacterial colony types was two and one at a depth of 10 and $20 \mathrm{~cm}$, respectively, with more occurrence of Gram negative than Gram positive bacteria in the polluted soils. Characterization and identification of the recovered bacterial colonies revealed that those strains belonged mainly to members of the genus Pseudomonas and was represented by the following species: $P$. maltophilia, $P$. putidae and $P$. mallaie. Other bacterial genera were also identified namely: Enterobacter, Acinetobacter, Bacillus, Micrococcus, Corynebacterium and Listeria (Table 1). Saadoun (17) reported the prevalence of members of the genus Pseudomonas in the hydrocarbon-contaminated soils with the occurrence of other genera, Enterobacter and Acinetobacter. Radwan et al. (16) reported a predominance of members of the genus Pseudomonas in addition to Bacillus, Streptomyces and Rhodococcus, in the various oil-polluted Kuwaiti Desert soil samples subjected to various types of management.

The colony morphology of the Streptomyces isolates on starch casein nitrate agar plates (SCNA) after 10 days of incubation at $27^{\circ} \mathrm{C}$ indicated that they were small $(1-10 \mathrm{~mm}$ diameter), discrete and leathery, initially relatively with smooth surface but later developed a weft of aerial mycelium that appeared granular, powdery and velvety.

\section{ACKNOWLEDGEMENTS}

This research was financed by the Higher Council for Science and Technology/ under the biodiversity of soil microorganisms in Jordan, grant No. 182/99.

\section{RESUMO}

\section{População microbiana de solos contaminados pelo derramamento de petróleo no deserto Jordão-Iraque (região de Badia)}

Analisou-se a população microbiana de solos contaminados pelo derramamento de petróleo em função das características do solo. Uma diminuição notável foi observada nas contagens e diversidade bacterianas, mas observou-se a prevalência de Pseudomonas em relação aos demais gêneros identificados em solos recentemente contaminados, quando comparado com solos com contaminação antiga.

Palavras-chave: bactéria, petróleo, fungos, solo, Streptomycetes

\section{REFERENCES}

1. Anonymous. (1990). Gezetteer of Jordan. Official standard names approved by the United States Board on Geographic Names. $2^{\text {nd }}$ ed. Fairfax, 337 pp. Washington, D.C.

2. Atlas, R.M. (1981). Microbial degradation of petroleum hydrocarbons: an environmental perspective. Microbiol. Rev., 45: 180-209.

3. Bossert, I.D.; Bartha, R. (1984). The fate of petroleum in soil ecosystems. In: Atlas, R.M. (ed.) Petroleum Microbiology. Macmillan Publishing Company, New York, p. 435-474.

4. Bossert, I.D.; Compeau, G.C. (1995). Cleanup of petroleum hydrocarbon contaminating in soil. In: Young, L.Y., Cerniglia, C.E. (ed.) Microbial Transformation and Degradation of Toxic Organic Chemicals. Wiley-Liss, Inc., New York, p. 77-128.

5. Civil Defense Department. (2001). Governate of Mafraq/Jordan. Report No. 824. $4^{\text {th }}$ July, 2001. Traffic Accidents on Mafraq-AlRuwaishid road during the period 1991-2001.

6. Dean-Ross, D. (1989). Bacterial abundance and activity in hazardous waste-contaminated soil. Bull. Environ. Contam. Toxicol., 43: 511517.

7. Jensen, V. (1975). Bacterial flora of soil after application of oily waste. Oikos, 26: 152-158.

8. Küster, E.; Williams, S.T. (1964): Selection media for the isolation of streptomycetes. Nature, 202: 928-929.

9. Leadbetter, E.R.; Foster, J.W. (1958). Studies of some methane utilizing bacteria. Arch. Microbiol. Rev., 30: 91-118.

10. Leahy, J.G.; Colwell, R.R. (1990). Microbial degradation of hydrocarbons in the environment. Microbiol. Rev., 54: 305-315.

11. Lianos, C.; Kjoller, A. (1976). Changes in the flora of soil fungi following oil waste application. Oikos, 27: 377-382.

12. Nelson, D.W.; Sommers, L.E. (1982). Total carbon, organic matter. In: Pape, A.L.; Miler, R.M.; Miller Keeney, D.R. (ed.) Methods Soil Analysis, Part II. Wisconsin, Madison, USA, 1982.

13. Nonomura, H. (1974). Key for classification and identification of 485 species of the streptomycetes included in the ISP. J. Ferm. Technol., 52: 78-92.

14. Palleroni, N.J. (1984). In: Holt, J.G., Krieg, N.R. (ed.) Bergey's Manual of Systematic Bacteriology. Williams and Wilkins, Baltimore, MD, vol. 1. p. 141-199.

15. Pinholt, Y.; Struwe, S.; Kjoller, A. (1979). Microbial changes during oil decomposition in soil. Holaret Ecology, 2: 195-200.

16. Radwan, S.S.; Sorkhoh, N.A.; Fardoun, F.; Al-Hasan, H. (1995). Soil management enhancing hydrocarbon biodegradation of the polluted Kuwaiti desert. Appl. Microbiol. Biotechnol., 44: 265-270.

17. Saadoun, I. (2002). Isolation and characterization of bacteria from crude petroleum oil contaminated soil and their potential to degrade diesel fuel. J. Basic Microbiol., 6: 420-428.

18. Shirling, E.B.; Gottlieb, D. (1966). Methods for characterization of streptomycetes species. Inter. J. System. Bacteriol., 16: 313-340.

19. Walter, U.; Beyer, M.; Klein, J.; Rehm, H.J. (1991). Degradation of pyren by Rhodococcus sp. Appl. Microbiol. Biotechnol., 34: 671676.

20. Williams, S.T.; Shameemullah, M.; Watson, E.T.; Mayfield, C.I. (1972). Studies on the ecology of actinomycetes in soil VI. The influence of moisture tension on growth and survival. Soil Biol. Biochem., 4: 215-225.

21. Williams, S.T.; Goodfellow, M.; Alderson G.; Wellington E.M.; Sneath P.H.; Sackin, M.J. (1983). Numerical classification of Streptomyces and related genera. J. Gen. Microbiol., 129; 1743-1813. 